\title{
PENGARUH SISTEM OLAH TANAH DAN APLIKASI MULSA BAGAS TERHADAP RESPIRASI TANAH PADA LAHAN PERTANAMAN TEBU (Saccharum officinarum L) AKHIR RATOON KEDUA DAN AWAL RATOON KETIGA
}

\author{
David Simamora, Ainin Niswati, Sri Yusnaini \& Muhajir Utomo \\ Jurusan Agroteknologi, Fakultas Pertanian Universitas Lampung \\ J1.Prof. Soemantri Brodjonegoro, No.1, Bandar Lampung 35145 \\ E-mail: Simamora.david28@gmail.com
}

\begin{abstract}
ABSTRAK
Penurunan kualitas tanah telah terjadi pada tanah perkebunan tebu PT GMP yang telah diusahakan secara intensif sejak tahun 1975. Oleh karena itu, usaha untuk memperbaiki kualitas tanah perkebunan tebu PT GMP perlu diusahakan antara lain dengan memanfaatkan mulsa limbah tebu (bagas) dan sistem olah tanah konservasi dalam bentuk tanpa olah tanah (TOT). Penelitian ini bertujuan untuk menduga pengaruh sistem olah tanah dan pemberian mulsa bagas terhadap aktivitas mikroorganisme tanah, dalam hal ini respirasi tanah.. Penelitian ini dirancang menggunakan RAK dan disusun secara split plot dengan 5 kali ulangan. Petak utama yaitu sistem olah tanah, yang terdiri dari tanpa olah tanah $\left(\mathrm{T}_{0}\right)$ dan olah tanah intensif $\left(\mathrm{T}_{1}\right)$. Anak petak adalah penggunaan mulsa bagas, yang terdiri dari tanpa mulsa bagas $\left(\mathbf{M}_{0}\right)$ dan mulsa bagas $80 \mathrm{t} \mathrm{ha}^{-1}\left(\mathbf{M}_{1}\right)$. Adapun kombinasi perlakuan yang diterapkan adalah sebagai berikut: $\mathrm{T}_{0} \mathrm{M}_{0}=\operatorname{tanpa}$ olah tanah $+\operatorname{tanpa}$ mulsa bagas, $\mathrm{T}_{0} \mathrm{M}_{1}=\operatorname{tanpa}$ olah tanah + mulsa bagas $80 \mathrm{t} \mathrm{ha}^{-1}, \mathrm{~T}_{1} \mathrm{M}_{0}=$ olah tanah intensif + tanpa mulsa bagas, dan $\mathrm{T}_{1} \mathrm{M}_{1}=$ olah tanah intensif + mulsa bagas $80 \mathrm{t}$ ha 1. Semua perlakuan diaplikasikan pupuk Urea dengan dosis $300 \mathrm{~kg} \mathrm{ha}^{-1}$, pupuk TSP $200 \mathrm{~kg} \mathrm{ha}^{-1}$, pupuk KCl $300 \mathrm{~kg} \mathrm{ha}^{-1}$, dan aplikasi bagas, blotong, dan abu (BBA) segar (5:3:1) $80 \mathrm{t} \mathrm{ha}^{-1}$. Data yang diperoleh diuji homogenitas ragamnya dengan Uji Bartlet dan aditivitasnya dengan Uji Tukey, serta anara dan dilanjutkan dengan Uji Beda Nyata Terkecil (BNT). Hasil penelitian menunjukkan bahwa perlakuan sistem olah tanah dan aplikasi mulsa bagas tidak berpengaruh nyata terhadap respirasi tanah baik pada umur 7 bulan setelah ratoon kedua dan umur 1 bulan setelah ratoon ketiga.
\end{abstract}

Kata kunci: mulsa bagas, olah tanah intensif, respirasi tanah, Saccharum officinarum L., tanpa olah tanah.

\section{PENDAHULUAN}

Tebu (Saccharum officinarum L.) merupakan tanaman penting sebagai penghasil gula dan juga sebagai salah satu kebutuhan pokok bagi penduduk Indonesia. Peningkatan jumlah penduduk, membutuhkan gula yang semakin meningkat pula, meskipun Indonesia merupakan salah satu negara penghasil gula di dunia, tetapi Indonesia masih mengalami kekurangan akibat konsumsi gula yang lebih tinggi dibandingkan dengan produksinya. Saat ini Pemerintah Indonesia sedang menggalakkan penanaman tebu untuk meningkatkan produksi gula. Salah satunya adalah perkebunan gula yang ada di Lampung adalah PT Gunung Madu Plantations (PT GMP).

Perusahaan PT GMP telah mengusahakan perkebunan tebu sejak tahun 1975 yang terus menerus melakukan pertanian intensif dengan pengolahan tanah dan penggunaan bahan-bahan kimia pertanian seperti pupuk dan pestisida (PT GMP, 2009). Pengelolaan tanah yang terlalu sering akan mengakibatkan menguatnya oksidasi bahan organik. Selain berakibat pada penurunan bahan organik terjadi juga penurunan ruang pori tanah karena hancurnya agregat tanah yang terbentuk sebelumnya (Soepardi, 1983). Selain itu, untuk memperbaiki kerusakan tanah dalam upaya peningkatan produksi, PT. GMP juga dapat menerapkan sistem olah tanah konservasi dalam bentuk tanpa olah tanah dan penambahan bahan organik kedalam tanah (Raya, 2011).

Segala perlakuan yang diberikan ke tanah akan mempengaruhi tanah dibawahnya, salah satunya adalah mikroorganisme tanah. Respirasi tanah merupakan suatu proses yang terjadi karena adanya kehidupan mikrobia yang melakukan aktifitas hidup dan berkembang biak dalam suatu masa tanah. Mikrobia dalam setiap aktifitasnya membutuhkan $\mathrm{O}_{2}$ atau mengeluarkan $\mathrm{CO}_{2}$ 
yang dijadikan dasar untuk pengukuran respirasi tanah (Anas, 1989).

Penelitian ini bertujuan untuk mempelajari pengaruh sistem olah tanah terhadap respirasi tanah, mempelajari pengaruh pengaplikasian mulsa bagas terhadap respirasi tanah, serta mempelajari interaksi antara sistem olah tanah dan aplikasi mulsa bagas terhadap respirasi tanah.

\section{BAHAN DAN METODE}

Penelitian ini dilaksanakan pada Februari 2013 sampai September 2013 pada lahan pertanaman tebu di PT. Gunung Madu Plantations (GMP), Lampung Tengah. Analisis tanah dilakukan di Laboratorium Ilmu Tanah, Fakultas Pertanian, Universitas Lampung.

Penelitian ini dirancang menggunakan RAK dan disusun secara split plot dengan 5 kali ulangan. Petak utama yaitu sistem olah tanah, yang terdiri dari tanpa olah tanah $\left(\mathrm{T}_{0}\right)$ dan olah tanah intensif $\left(\mathrm{T}_{1}\right)$. Anak petak adalah aplikasi mulsa bagas, yang terdiri dari tanpa mulsa bagas $\left(\mathrm{M}_{0}\right)$ dan mulsa bagas $80 \mathrm{tha}^{-1}\left(\mathrm{M}_{1}\right)$. Dengan demikian terbentuk 4 kombinasi perlakuan, yaitu $\mathrm{T}_{0} \mathrm{M}_{0}$ = tanpa olah tanah + tanpa mulsa bagas, $\mathrm{T}_{0} \mathrm{M}_{1}=$ tanpa olah tanah + mulsa bagas $80 \mathrm{tha}^{-1}, \mathrm{~T}_{1} \mathrm{M}_{0}=$ olah tanah intensif + tanpa mulsa bagas, $\mathrm{T}_{1} \mathrm{M}_{1}=$ olah tanah intensif + mulsa bagas $80 \mathrm{tha}^{-1}$. Semua perlakuan diaplikasikan pupuk Urea dengan dosis $300 \mathrm{~kg} \mathrm{ha}^{-1}$, TSP $200 \mathrm{~kg} \mathrm{ha}^{-1}$, $\mathrm{KCl} 300 \mathrm{~kg} \mathrm{ha}^{-1}$, dan aplikasi bagas, blotong, dan abu (BBA) segar (5:3:1) $80 \mathrm{t} \mathrm{ha}^{-1}$. Data yang diperoleh dianalisis dengan sidik ragam pada taraf $1 \%$ dan 5\%, yang sebelumnya telah diuji homogenitas ragamnya dengan Uji Bartlett dan aditivitasnya dengan Uji Tukey. Rata-rata nilai tengah diuji dengan uji BNT pada taraf $1 \%$ dan 5\%. Untuk mengetahui hubungan antara respirasi tanah dengan $\mathrm{C}$-organik, $\mathrm{pH}$, kadar air, dan suhu tanah dilakukan uji korelasi.

Penelitian ini menggunakan lahan pertanaman tebu yang diset untuk dijadikan lahan penelitian jangka panjang yang dimulai pada bulan juni 2010 sampai 10 tahun kedepan. Penelitian ini menggunakan dua perlakuan olah tanah yaitu olah tanah intensif dan tanpa olah tanah. Pada petak olah tanah intensif $\left(\mathrm{T}_{1}\right)$, tanah diolah sesuai dengan sistem pengolahan tanah sebanyak 3 kali pengolahan, yaitu menggunakan bajak piringan yang berfungsi mencacah tunggul tebu, memecah dan membalikkan tanah. Pengolahan tanah kedua tetap menggunakan bajak piringan, tetapi arah kerjanya tegak lurus dengan pengolahan tanah pertama, berfungsi untuk menghaluskan tanah dan sekaligus untuk mencacah ulang tunggul tebu. Pengolahan tanah yang ketiga menggunakan bajak singkal untuk membalikkan tanah bawahan ke atas sekaligus memecahkan lapisan kedap air sehingga mampu mendukung perkembangan akar tanaman. Sedangkan pada petak tanpa olah tanah $\left(\mathrm{T}_{0}\right)$ tanah tidak olah sama sekali. Campuran bagas, blotong, dan abu (BBA) diaplikasikan dengan cara ditebar di permukaan tanah dengan dosis $80 \mathrm{tha}^{-1}$ bersamaan pada saat aplikasi BBA pada petak olah tanah intensif.

Pengukuran Respirasi Tanah di Lapangan dengan Metode Verstraete (Anas,1986). Pengukuran respirasi tanah langsung dilakukan di lapangan, dengan mengambil sampel sebanyak 2 kali. Pengambilan sampel dilakukan pada akhir ratoon kedua berumur 7 bulan dan awal ratoon ketiga berumur 1 bulan. Pengambilan sampel dilakukan pada pagi dan sore hari. Pengambilan sampel respirasi tanah dilakukan diantara baris tanaman tebu dengan jarak sekitar $0,8 \mathrm{~cm}$. Pengukuran respirasi tanah dilakukan dengan menutup permukaan tanah menggunakan toples yang di dalamnya telah diberikan botol film yang berisi $10 \mathrm{ml} \mathrm{KOH} \mathrm{0,1} \mathrm{N}$. Untuk kontrol dilakukan hal yang sama, tetapi permukaan tanah ditutup dengan plastik sehingga $\mathrm{KOH}$ tidak dapat menangkap $\mathrm{CO}_{2}$ yang keluar dari tanah. Agar tidak terjadi kebocoran, toples dibenamkan kedalam tanah 2-3 cm. Pengukuran ini dilakukan selama 2 jam. Pengukuran respirasi tanah dilakukan dengan meletakkan 2 buah toples pada setiap petak percobaan, dimana 1 toples sebagai perlakuan dan 1 toples lainnya sebagai kontrol. Setelah pengukuran di lapangan selesai $\mathrm{KOH}$ hasil pengukuran dititrasi di laboratorium untuk menentukan kuantitas $\mathrm{C}-\mathrm{CO}_{2}$ yang dihasilkan. Titrasi dilakukan dengan cara memindahkan $\mathrm{KOH}$ hasil pengukuran kedalam gelas erlenmeyer dan ditambahkan 2 tetes fenolptalin, sehingga warna berubah menjadi merah muda dan kemudian dititrasi dengan $\mathrm{HCl}$ sampai warna merah muda hilang (larutan berwarna bening), volume $\mathrm{HCl}$ yang diperlukan dicatat. Kemudian kedalam larutan ditambahkan 2 tetes metil orange sehingga larutan berwarna kuning, dan larutan dititrasi kembali dengan $\mathrm{HCl}$ hingga warna kuning berubah menjadi warna merah muda. $\mathrm{HCl}$ yang digunakan berhubungan langsung dengan jumlah $\mathrm{CO}_{2}$ yang difiksasi. Pada kontrol juga dilakukan hal yang sama. Jumlah $\mathrm{CO}_{2}$ dihitung dengan mengunakan formula:

$$
C-\mathrm{CO}_{2}=\frac{(a-b) \times t \times 12}{T \times \pi \times r^{2}}
$$

Keterangan : $\mathrm{C}-\mathrm{CO}_{2}=\mathrm{mg} \mathrm{jam}^{-1} \mathrm{~m}^{-2}, \mathrm{a}=\mathrm{ml} \mathrm{HCl}$ untuk contoh tanah (setelah ditambahkan metil orange), $\mathrm{b}=\mathrm{ml} \mathrm{HCl}$ untuk kontrol (setelah ditambahkan metil orange), $\mathrm{t}=$ normalitas $\mathrm{HCl}(N), \mathrm{T}=$ waktu pengukuran (jam), $\mathrm{r}=$ jari-jari tabung toples $(\mathrm{cm})$. 


\section{HASIL DAN PEMBAHASAN}

Hasil penelitian (Tabel 1) menunjukkan perlakuan pengolahan tanah dan pemberian mulsa bagas tidak berpengaruh nyata terhadap respirasi tanah pada saat tanaman tebu berumur 7 bulan setelah ratoon kedua dan 1 bulan setelah ratoon ketiga, serta tidak terdapat interaksi antara pengolahan tanah dan pemberian mulsa bagas.

Hal ini sejalan dengan penelitian Cahyono (2013) yang telah melakukan penelitian pada tahun kedua dimana dari hasil penelitian menunjukkan belum adanya pengaruh sistem olah tanah dan aplikasi mulsa bagas terhadap respirasi tanah. Sedangkan, menurut hasil penelitian Sucipto (2011) menyatakan bahwa dalam kurun waktu yang singkat penerapan perlakuan sistem olah tanah belum memperlihatkan pengaruh yang nyata terhadap kandungan bahan organik tanah. Perbedaan lamanya waktu penelitian diduga menjadi faktor utama belum adanya pengaruh terhadap penelitian ini. Waktu penelitian yang dilakukan selama 3 tahun diduga masih belum memungkinkan terjadinya perubahan signifikan

Tabel 1. Ringkasan uji signifikasi respirasi tanah saat tanaman tebu berumur 7 bulan setelah ratoon kedua dan 1 bulan setelah ratoon ketiga.

\begin{tabular}{lcc}
\hline \multirow{2}{*}{ Sumber Keragaman } & \multicolumn{2}{c}{ Waktu Penga matan } \\
\cline { 2 - 3 } & 7 BSR2 & 1 BSR3 \\
\hline Olah Tanah (PU) & tn & tn \\
Mulsa (AP) & tn & tn \\
Interaksi & tn & tn \\
\hline
\end{tabular}

Keterangan: $\mathrm{tn}=$ tidak berbeda nyata pada taraf nyata $5 \%$ dan $1 \%, \mathrm{PU}=$ petak utama, $\mathrm{AP}=$ anak petak, $\mathrm{BSR} 2=$ bulan setelah ratoon kedua, BSR3 = bulan setelah ratoon ketiga. pada lahan percobaan, sehingga pengaruh perlakuan olah tanah serta pemberian mulsa belum terlihat pengaruhnya terhadap respirasi tanah.

Gambar 1 menunjukkan produksi respirasi tanah pada saat tanaman tebu berumur 7 bulan setelah ratoon kedua (BSR2) lebih tingi dibandingkan dengan tanaman berumur 1 bulan setelah ratoon ketiga (BSR3), dimana tanaman tebu berumur 7 bulan setelah ratoon kedua (BSR2) pada perlakuan tanpa olah tanah tanpa mulsa bagas $\left(\mathrm{T}_{0} \mathrm{M}_{0}\right)$, dan perlakuan tanpa olah tanah diberi mulsa bagas $\left(\mathrm{T}_{0} \mathrm{M}_{1}\right)$ produksi respirasi tanah berkisar $29,25 \mathrm{mg} \mathrm{jam}^{-1} \mathrm{~m}^{-2}$ dan $28,86 \mathrm{mg} \mathrm{jam}^{-1} \mathrm{~m}^{-2}$, sedangkan pada perlakuan olah tanah intensif tanpa mulsa bagas dan perlakuan olah tanah intensif diberi mulsa bagas produksi respirasi tanahnya berkisar $24,57 \mathrm{mg} \mathrm{jam}^{-1}$ $\mathrm{m}^{-2}$ dan 23,4 $\mathrm{mg} \mathrm{jam}^{-1} \mathrm{~m}^{-2}$. Pada tanaman tebu berumur 1 bulan setelah ratoon ketiga (BSR3) dimana pada perlakuan tanpa olah tanah tanpa mulsa bagas $\left(\mathrm{T}_{0} \mathrm{M}_{0}\right)$ dan perlakuan tanpa olah tanah diberi mulsa bagas $\left(\mathrm{T}_{0} \mathrm{M}_{1}\right)$ produksi respirasi tanah berkisar 20,67 mg jam ${ }^{1} \mathrm{~m}^{-2}$ dan $24,57 \mathrm{mg} \mathrm{jam}^{-1} \mathrm{~m}^{-2}$, sedangkan pada perlakuan olah tanah intensif tanpa diberi mulsa dan perlakuan olah tanah intensif diberi mulsa bagas produksi respirasi tanah berkisar 20,28 mg jam ${ }^{-1} \mathrm{~m}^{-2}$ dan $19,89 \mathrm{mg} \mathrm{jam}^{-1}$ $\mathrm{m}^{-2}$.

Penelitian ini dilakukan mulai tahun 2010, respirasi pertama diukur pada ratoon pertama dimana produksi respirasi tanahnya cenderung lebih tinggi (Cahyono, 2013). PT GMP menerapkan sistem pengolahan tanah, dimana konsep pengolahan tanah yang diterapkan tersebut dimaksudkan untuk memperbaiki kemampuan tanah dalam menyimpan dan menyediakan hara, memperbesar volume perakaran, dan pelestarian (konservasi) serta penambahan bahan organik dalam tanah (PT GMP, 2009). Sedangkan, hasil penelitian menunjukkan bahwa produksi respirasi tanah ratoon kedua lebih tinggi daripada ratoon pertama. Hal ini diduga disebabkan karena pemberian mulsa bagas pada ratoon kedua dan ketiga yang ditambahkan pada setiap

Tabel 2. Koefisien korelasi antara respirasi tanah dengan C-organik tanah, $\mathrm{pH}$ tanah, Suhu tanah, dan Kadar air tanah pada saat tanaman tebu berumur 7 bulan setelah ratoon kedua dan 1 bulan setelah ratoon ketiga.

\begin{tabular}{cllll}
\hline Respirasi tanah & C-organik & $\mathrm{pH}$ & Suhu & Kadar air \\
\hline \multicolumn{5}{c}{ Nilai r } \\
\hline 7 BSR2 & $0,43 \mathrm{tn}$ & $0,22 \mathrm{tn}$ & $-0,08 \mathrm{tn}$ & $-0,03 \mathrm{tn}$ \\
1 BSR3 & $0,21 \mathrm{tn}$ & $0,07 \mathrm{tn}$ & $-0,18 \mathrm{tn}$ & $-0,02 \mathrm{tn}$ \\
\hline
\end{tabular}

Keterangan: $\mathrm{tn}=$ tidak berbeda nyata pada taraf nyata $5 \%$ dan $1 \%, \mathrm{BSR} 2=$ bulan setelah ratoon kedua, $\mathrm{BSR} 3=$ bulan setelah ratoon ketiga. 
Tabel 3. Hasil analisis C-organik tanah, $\mathrm{pH}$ tanah, Suhu tanah, dan Kadar air tanah pada saat tanaman tebu berumur 7 bulan setelah ratoon kedua dan 1 bulan setelah ratoon ketiga.

\begin{tabular}{ccccccc}
\hline \multirow{2}{*}{ Perlakuan } & C-organik $(\%)$ & $\mathrm{pH}\left(\mathrm{H}_{2} \mathrm{O}\right)$ & \multicolumn{2}{c}{ Suhu $\left({ }^{\circ} \mathrm{C}\right)$} & \multicolumn{2}{c}{ Kadar Air $(\%)$} \\
\cline { 2 - 7 } & 7 & 7 & 7 & 1 & 7 & 1 \\
& $\mathrm{BSR} 2$ & $\mathrm{BSR} 2$ & $\mathrm{BSR} 2$ & $\mathrm{BSR} 3$ & $\mathrm{BSR} 2$ & BSR3 \\
\hline $\mathrm{T}_{1} \mathrm{M}_{0}$ & 1,20 & 5,33 & 28,58 & 28,60 & 16,61 & 16,59 \\
$\mathrm{~T}_{1} \mathrm{M}_{1}$ & 1,30 & 5,40 & 28,50 & 28,48 & 17,97 & 19,19 \\
$\mathrm{~T}_{0} \mathrm{M}_{0}$ & 1,33 & 5,44 & 28,48 & 28,58 & 19,12 & 17,97 \\
$\mathrm{~T}_{0} \mathrm{M}_{1}$ & 1,48 & 5,24 & 28,40 & 27,70 & 28,40 & 20,90 \\
\hline
\end{tabular}

Keterangan : $7 \mathrm{BSR} 2=7$ bulan setelah ratoon kedua, $1 \mathrm{BSR} 3=1$ bulan setelah ratoon ketiga, $\mathrm{T}_{1}=$ olah tanah intensif, $\mathrm{T}_{0}=$ tanpa olah tanah, $\mathrm{M}_{1}=$ mulsa bagas, $\mathrm{M}_{0}=$ tanpa mulsa bagas.

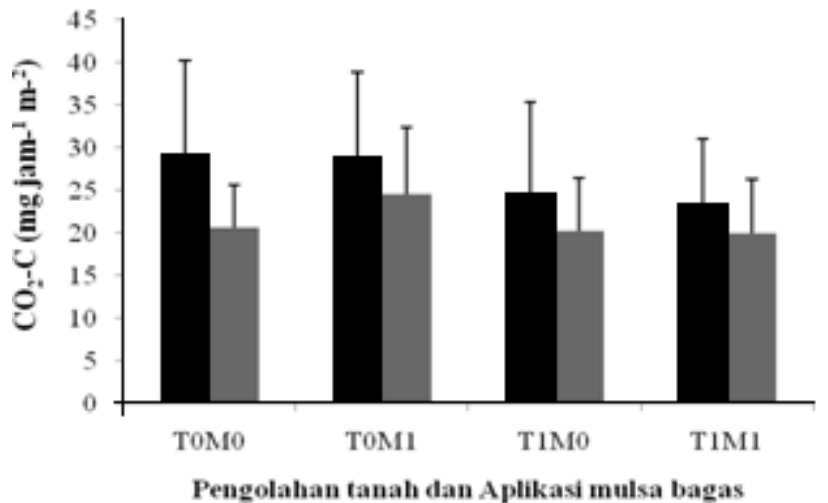

Gambar 1. Pengaruh sistem olah tanah dan aplikasi mulsa bagas terhadap respirasi tanah pada pengamatan 7 bulan setelah ratoon kedua dan 1 bulan setelah ratoon ketiga $\left(T_{0}=\right.$ Tanpa olah tanah; $\mathrm{T}_{1}=$ Olah tanah intensif; $\mathrm{M}_{0}=$ Tanpa mulsa; $\mathrm{M}_{1}=$ Mulsa bagas $80 \mathrm{t} \mathrm{ha}^{-1}$; tongkat pada grafik batang menunjukkan standar deviasi). $\mathbf{\square}=7$ BSR2, $\square=1$ BSR3.

plot pada lahan penelitian dimungkinkan perlahan-lahan mulai terdekomposisi dengan sempurna akibat populasi mikroorganisme yang ada di dalam tanah semakin banyak.

Pada Tabel 1 juga menunjukkan bahwa pemberian mulsa bagas tidak berpengaruh nyata terhadap respirasi tanah. Hal ini diduga karena $\mathrm{C} / \mathrm{N}$ rasio mulsa bagas yang sangat tinggi (C/N 86) (Sucipto, 2011) menyebabkan mulsa bagas belum terdekomposisi (terombak) secara keseluruhan atau butuh waktu yang sangat lama untuk terdekomposisi secara keseluruhan menjadi C-organik tanah dan unsur hara lainnya, karena waktu yang dibutuhkan untuk pembentukan C-organik tanah cukup lama.
Pada Tabel 2 dapat dilihat bahwa perlakuan sistem olah tanah dan aplikasi mulsa bagas tidak menunjukkan korelasi terhadap C-organik, $\mathrm{pH}$ tanah, suhu tanah, dan kadar air tanah, sedangkan pada Tabel 3 menunjukkan hasil analisis C-organik tanah, $\mathrm{pH}$ tanah, suhu tanah, dan kadar air tanah pada saat tanaman tebu berumur 7 bulan setelah ratoon kedua dan 1 bulan setelah ratoon ketiga. Hal ini menunjukkan bahwa tinggi rendahnya respirasi tanah pada penelitian ini tidak tergantung pada C-organik tanah, $\mathrm{pH}$ tanah, suhu tanah dan kadar air tanah. Belum berpengaruhnya mulsa bagas terhadap C-organik, $\mathrm{pH}$, suhu, dan kadar air tanah di duga karena kandungan $\mathrm{C} / \mathrm{N}$ rasio bagas yang sangat tinggi C/N 86 (Sucipto, 2011). Hal ini juga dikarenakan waktu penelitian yang digunakan baru berjalan 3 tahun sehingga mulsa bagas belum terdekomposisi (terombak) secara keseluruhan menjadi C-organik tanah dan unsur hara lainnya, karena waktu yang dibutuhkan untuk pembentukan C-organik tanah cukup lama. Hasil uji korelasi menunjukan bahwa respirasi tanah tidak berkorelasi dengan kandungan $\mathrm{C}$-organik tanah, $\mathrm{pH}$ tanah, kadar air tanah dan, suhu tanah. Menurut Buchari (1999), karbon tanah merupakan variabel yang penting dalam memacu aktivitas mikroorganisme tanah. Hal ini dikarenakan karbon dalam tanah berfungsi sebagai sumber energi untuk memacu aktivitas mikroorganisme untuk melakukan proses dekomposisi bahan organik (Kirana, 2010).

\section{KESIMPULAN}

Dari hasil penelitian dapat disimpulkan bahwa sistem pengolahan tanah tidak mempengaruhi respirasi tanah pada umur 7 bulan setelah ratoon kedua dan 1 bulan setelah ratoon ketiga. Aplikasi mulsa bagas tidak mempengaruhi respirasi tanah pada umur 7 bulan setelah ratoon kedua dan 1 bulan setelah ratoon ketiga. Tidak 
terdapat interaksi antara sistem olah tanah dan pemberian mulsa bagas pada umur 7 bulan setelah ratoon kedua dan 1 bulan setelah ratoon ketiga terhadap respirasi tanah.

\section{SANWACANA}

Ucapan terima kasih disampaikan kepada PT. GMP Lampung dan YNU Jepang yang telah memberikan dana dan izin untuk dapat melakukan penelitan.

\section{DAFTAR PUSTAKA}

Anas, I. 1989. Biologi Tanah Dalam Praktek. Pusat Antar Universitas Bioteknologi. Bogor

Buchari, H. 1999. Penetapan Karbon Microbial (C-mik) pada Dua Tipe Penggunaan Lahan (alang-alang dan hutan) dengan Metode Fumigasi Ekstraksi sebagai Indikator Degradasi Tanah. Makalah khusus Program Pascasarjana. Institut Pertanian Bogor. Bogor. 29 hlm.

Cahyono, B. 2013. Pengaruh Sistem Olah Tanah dan Aplikasi Mulsa Bagas Terhadap Respirasi Tanah pada Lahan Pertanaman Tebu (Saccharum officinarum L.) PT Gunung Madu Plantations (PT GMP). (Skripsi). Universitas Lampung. 51 hlm.
PT GMP. 2009. Pengolahan Tanah. www. Gunungmadu.co.id. Diakses pada tanggal : 27 Februari 2013.

Raya. 2011. Pengaruh jarak tanam terhadap pertumbuhan dan produksi tanaman tebu. http://www.scribd.com/doc/49072312/ Proposal-padi. Diakses pada tanggal : 26 April 2013.

Soepardi, G. 1993. Sifat dan Ciri Tanah. FapertaIPB. Bogor. $591 \mathrm{hlm}$.

Sucipto. 2011. Pengaruh Sistem Olah tanah dan Aplikasi Mulsa Bagas terhadap Kandungan biomassa Karbon Mikroorganisme Tanah. (Skripsi). Universitas Lampung. $58 \mathrm{hlm}$.

Kirana. 2010. Pengaruh Sistem Olah Tanah Konservasi Jangka Panjang terhadap Biomassa Karbon Mikroorganisme Tanah (C-mik) dan Produktivitas Tanaman Jagung di Tanah Ultisol. (Skripsi). Universitas Lampung. Bandar Lampung. $63 \mathrm{hlm}$. 